\title{
Progress and Future of Breakthrough Low-carbon Steelmaking Technology (ULCOS) of EU
}

\author{
Yan Junjie \\ Wheel and Axle Department of Maanshan Iron and Steel Co., Ltd., Maanshan, China \\ Email address: \\ 147926758@qq.com
}

To cite this article:

Yan Junjie. Progress and Future of Breakthrough Low-carbon Steelmaking Technology (ULCOS) of EU. International Journal of Mineral Processing and Extractive Metallurgy. Vol. 3, No. 2, 2018, pp. 15-22. doi: 10.11648/j.ijmpem.20180302.11

Received: May 28, 2018; Accepted: June 26, 2018; Published: July 24, 2018

\begin{abstract}
The $\mathrm{CO}_{2}$ emitted by iron and steel industry accounts for $6 \%$ of the global anthropogenic $\mathrm{CO}_{2}$ emission. As the control of $\mathrm{CO}_{2}$ emission becomes increasingly stringent all over the world, the iron and steel industry now is facing an unprecedented crisis. And now even the most advanced technologies for reducing carbon emission have reached the bottleneck, so many countries in the world are striving to develop the breakthrough technologies for significantly reducing the carbon emission. The current progress and future research of steelmaking program with ultra-low $\mathrm{CO}_{2}$ emission in Europe are stated, among which TGR-BF, HIsarna, ULCORED, ULCOWIN and ULCOLYSIS are considered to be the most promising technologies. Combined with the technology of carbon capture and storage, $\mathrm{CO}_{2}$ emission can be reduced by as much as $80 \%$. Compared with the traditional technologies, investment cost and operating cost are much lower.
\end{abstract}

Keywords: Top Gas Recovery, HIsarna, ULCORED, ULCOWIN and ULCOLYSIS, Low Carbon, Environment Protection, ULCOS

\section{Introduction}

The steel industry is a pillar industry in the economic development of modernized countries and plays an important role in promoting industrial and economic development. However, the steel industry is also a capital - technology energy - technology - intensive industry. Its energy consumption accounts for $5 \%$ of the global total energy consumption and contributes $6 \%$ of the global anthropogenic $\mathrm{CO}_{2}$ emissions [1]. Producing 1 ton of steel consumes 35.4 GJ of energy and emits 1.8 ton of $\mathrm{CO}_{2}$ [2]. In the current context of strict global resources and environmental protection policies, the steel industry characterized by high energy consumption and high pollution is facing greater environmental pressure. At present, the main energy-saving and emission-reduction technologies in the steel industry have reached the theoretical limit of emission reduction [3]. In the past ten years, many countries in the world have begun to develop breakthrough low-carbon steelmaking technologies that can significantly reduce $\mathrm{CO}_{2}$ emissions. Among them, Ultra-low $\mathrm{CO}_{2}$ Steelmaking (ULCOS) program of European Union has he most extensive research scope.

\section{Progress of Low-carbon Production Technologies in Global Steel Industry}

\subsection{ULCOS Program in EU}

With the release of the EU "Climate and Energy Policy Objectives of 2030", EU countries have introduced more stringent environmental protection regulations and emission standards. In particular, the establishment of the European Union's Emission Trading System (EU-ETS) has greatly increased the cost of carbon emissions in various industries. In this context, the high energy consumption and high pollution of the European steel industry have had to increase energy conservation and emission reduction to the same level as the growth profits. The steel industry of European Union established the European Steel Technology Platform (ESTEP) in 2003. Its members include major European steel companies, suppliers and associations, as well as universities and scientific institutions. European Commission and the governments of member states also send representatives to participate in the work of the management committee.

ESTEP started Ultra-low $\mathrm{CO}_{2}$ Steelmaking program 
(ULCOS) in 2004, with the purpose of developing new low-carbon steelmaking technology that can reduce $\mathrm{CO}_{2}$ emissions per ton of steel by $50 \%$ from its current best level $(2$ $\mathrm{t}-\mathrm{CO}_{2} / 1 \mathrm{t}$-steel) by the year 2050 . The main members of the ULCOS program are 48 companies from 15 European countries, involving steel, gas, equipment manufacturing, metallurgical engineering, research institutes and universities. The board is chaired by ArcelorMittal, and the members of the board of directors include Tata Steel. ThyssenKrupp Group, VAI, Swedish Steel and LKAB. The program has two phases: the first phase (ULCOS I, 2004-2010) is the theoretical research and pilot-test phase, and the second phase (ULCOS II, 2010-2015) is the in-depth development phase for the preparation of industrialized application of the technical solution [4-5].

\subsection{COURSE 50 Program in Japan}

$\mathrm{CO}_{2}$ Ultimate Reduction in Steelmaking Process by Innovative Technology for Cool Earth 2050(COURSE 50) is a national research program of Japan aimed at developing the technologies to reduce $\mathrm{CO}_{2}$ emissions from the blast furnace and to capture, separate, recover $\mathrm{CO}_{2}$ from blast furnace gas (BFG). The program is initiated by the Japan Iron and Steel Federation and financed by New Energy and Industrial Technology Development Organization. Nippon Steel \& Sumitomo, Kobe Steel, JFE Steel, and Nisshin Iron \& Steel, etc., jointly participate [6]. The initial objective is the development of new technologies that can reduce $\mathrm{CO}_{2}$ emissions from blast furnace, including reforming technology of coke oven gas to increase hydrogen concentration, and the reaction control technology to reduce carbon reducing agent by using hydrogen, and the technology for manufacturing high-strength and high-reactivity coke suitable for hydrogen reduction reaction; the other objective is to develop the technology for separating and recovering $\mathrm{CO}_{2}$ through chemical and physical adsorption methods using waste heat available within the steelworks, including the development of chemical and physical absorption device for absorbing $\mathrm{CO}_{2}$ from blast furnace gas, the novel amine-based absorbents and catalysts, and a system combining chemical absorption and physical adsorption, and the technology that utilizes waste heat resources from steel mills to reduce the energy required to separate and recover $\mathrm{CO}_{2}$. COURSE 50 program has two steps: Step 1 (2008-2012) aims at the developing the fundamental technologies which was completed as per the program schedule, Step 2 (2013-2017) aims at developing the integrated technologies based on the results of the fundamental technologies. It is predicted that the industrialized application can be realized by 2030, and the export and transfer of the technology can be realized by 2050 .

\subsection{POSCO Program in South Korea}

As one of the most competitive and most respected steel companies in the world, Pohang Iron and Steel Company is developing innovative technology to reducing energy consumption and promoting Clean Development
Mechanism (CDM) programs to reduce greenhouse gas emission.

POSCO's low-carbon ironmaking technology in South Korea includes the following aspects. (1) Low-carbon ironmaking technology-FINEX. Previously, two FINEX plants have been operating in a stable manner. In 2014, another FINEX plant with an annual capacity of 2 million tons was put into operation. This device adopts a three-stage fluidized bed instead of the original four-stage fluidized bed, making the design even more efficient and compact, and the investment was reduced by $15 \%$. (2) Pure hydrogen blast furnace ironmaking technology. The short-term goal is to use the by-produced gases produced in the steel production process to produce hydrogen that can be used to reduce iron ore. The medium-and-long-term goal is to develop the technology that can produce high-purity hydrogen in large quantities at low cost. (3) Carbon capture and separation technology. The technology of absorbing $\mathrm{CO}_{2}$ with the ammonia from blast furnace gas and using low-and-medium-temperature waste heat generated during steelmaking process as energy to absorb $\mathrm{CO}_{2}$ was developed to reduce cost. The program was established in 2006 and started construction in December 2008. The test equipment has a processing capacity of $50 \mathrm{~m}^{3} / \mathrm{h}$, with the $\mathrm{CO}_{2}$ capture efficiency over $90 \%$ and $\mathrm{CO}_{2}$ volume concentration no less than $95 \%$. The second set of demonstration equipment has been in operation since 2010 with a processing capacity of $1000 \mathrm{~m}^{3} / \mathrm{h}$. It was anticipated that the $\mathrm{CO}_{2}$ daily capture capacity could reach to 10 tons a few years later. (4) Sensible heat recovery for power generation. POSCO also developed the heat recovery technology of flue gas that uses thermal siphon effect to recover heat energy from flue gas for power generation. The preparation for flue gas heat recovery test equipment was started in 2010 [7].

\subsection{AISI Program in USA}

This U.S. low-carbon steelmaking research is jointly funded by the U.S. Department of Energy and the U.S. Steel Association, and organized by the top universities in the field of metallurgy to develop new technologies that can significantly reduce $\mathrm{CO}_{2}$ emissions from steel production, including the use of several kinds of clean energy and development of $\mathrm{CO}_{2}$ capture and separation technology.

Two carbon-free iron making methods has been investigated: (1) Molten oxidation electrolysis (MOE). It aims at eradicating blast furnace and coke oven, reduce $\mathrm{CO}_{2}$ emissions and produce huge amount oxygen with commercial value. (2) Hydrogen flash melting. In this process, BF fuel coke is replaced by hydrogen, natural gas, coal or a combination. In 2011, laboratory testing was successfully performed on a smaller-scale oxy-fuel burner for heat supply in an industrial operation.

AISI members are developing a high-productivity; low-energy iron making process called Paired Straight Hearth Furnace, which can process both steel plant waste and virgin iron materials, using coal instead of coke. 


\subsection{Other Programs}

The National Steel Program of Canada's Steel Production
Association is committed to replacing fossil fuels with biomass fuels currently used in steel production.

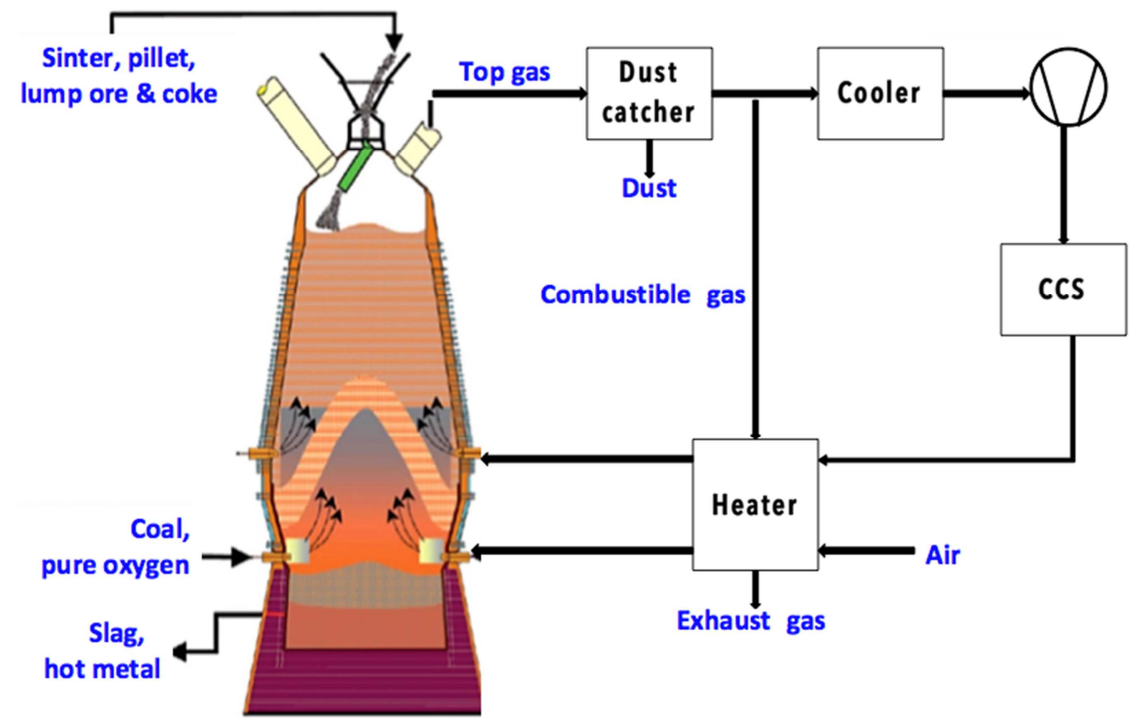

Figure 1. Different versions of TGR-BF process.

Arcelor-Mettal Brazil has developed biomass carbon smelting technology, using charcoal made of artificially planted eucalyptus forests as fuel, and has applied this technology to small scale charcoal blast furnaces (annual production of 30 kilo-tons).

Australia has undertaken two main $\mathrm{CO}_{2}$ emissions reduction programs: (1) One is using biomass as the fuel for blast furnace, which is a carbon neutral and zero emissions process. (2) The other is a heat recovery process from molten slags by dry granulation in blast furnace [8].

Among all these programs, ULCOS has the most extensive research scope, including not only several kinds of innovative low-carbon steelmaking technologies, but also biomass utilization, carbon dioxide capture and storage, and the research on European and Global future scenario of different carbon constraints.

\section{Current Progress of ULCOS Program}

At the ULCOS I theoretical study and pilot test stage (2004-2010), program researchers used mathematical simulations and laboratory tests to evaluate energy consumption, $\mathrm{CO}_{2}$ emissions, operating costs, and sustainability of 80 different technologies. Finally, four of the most promising technologies were selected for further research and commercialization, namely, top gas recovery-blast furnace (TGR-BF) and new direct reduction process (ULCORE), new smelting reduction process (HIsarna) and iron ore electrolysis (ULCOWIN, ULCOLYSIS). In addition, hydrogen and biomass reduction ironmaking technologies were developed as support technology. At the ULCOS II industrial demonstration stage (2010-2015), the processes, tool and equipment, economy, and stability of these technologies were tested and improved on a pilot plant built by retrofitting equipment from several comprehensive steelmaking plants in Europe [9].

\subsection{Top Gas Recycling Blast Furnace (TGR-BF)}

Top gas recycling blast furnace uses top gas to absorb $\mathrm{CO}_{2}$ inside blast furnace acting as a reducing agent (TGR-BF). The TGR-BF process has four versions. Except Version 2 has been abandoned due to its poor $\mathrm{CO}_{2}$ emission reduction effect, the other three versions have been tested and verified.

1. Version 1 , the decarbonized top gas at $900^{\circ} \mathrm{C}$ is inject into blast furnace through the tuyeres at furnace stack, and the decarbonized cold top gas, oxygen and pulverized coal are injected into blast furnace through the tuyeres at furnace hearth. The expected carbon saving is $22 \%$.

2. Version 2 , the decarbonized top gas at $1250^{\circ} \mathrm{C}$ is injected into blast furnace through the tuyeres at furnace stack. The expected carbon saving is $24 \%$.

3. Version 3, the decarbonized top gas at $900^{\circ} \mathrm{C}$ is inject into blast furnace through the tuyeres at furnace stack, and the decarbonized top gas at $1250^{\circ} \mathrm{C}$, oxygen and pulverized coal are injected into blast furnace through the tuyeres at furnace hearth. The expected carbon saving is $26 \%$.

The research team studied heat and mass balance models, tuyere and raceway model and model of blast furnace internal state. They also conducted mathematical simulations of the three plans and studied the effects of reduction, thermal degradation, and soft-melt behavior through lots of laboratory tests.

In order to test the operation result of the three versions, tests were carried out on an experimental blast furnace (EBF) in the plant of LKAB in Luleå, Sweden in 2007. The blast furnace was reformed before the test. In order to remove $\mathrm{CO}_{2}$ from the top gas, a vacuum pressure swing adsorption (VPSA) device was installed, and vertical gas injection devices were installed at the tuyeres of furnace stack which is connected to 
the original hot-blast stove. The distribution valve was used to adjust the gas distribution at the tuyeres of stack and hearth.

During the three tests, the coal and coke input was reduced from $530 \mathrm{~kg}$ to $400 \mathrm{~kg}$, and the carbon input significantly decreased from $470 \mathrm{~kg} /$ thm to $350 \mathrm{~kg} / \mathrm{thm}$ (thm=ton hot metal). The top gas recovery rate of Version 3 can reach $72 \%$, with carbon consumption reduced by $15 \%$, and the recovery rate of top gas of Version 4 can reach $90 \%$, with carbon consumption decreased by $24 \%$. In addition, the consumption of coal and coke in TGR-BF process is reduced by $123 \mathrm{~kg} / \mathrm{thm}$ (thm=ton of hot metal) compared with benchmark operation. Moreover, the more $\mathrm{CO}$ and $\mathrm{H}_{2}$ is injected, the higher the reduction rate of iron ore is, and the consumption amount of coal and coke can be reduced by $17 \mathrm{~kg}$ for every additional cubic meter of $\mathrm{CO}$ and $\mathrm{H}_{2}$.

VPSA unit was operating stably, it can treat $97 \%$ of top gas from the blast furnace. The average volume fraction of $\mathrm{CO}_{2}$ in injected gas is about $2.67 \%$ and the $\mathrm{CO}$ recovery rate is $88 \%$, meeting the requirements of quantity and quality.

Combined with VPSA and CCS units, the $\mathrm{CO}_{2}$ emissions reduced by TGR-BF unit can reach to $1270 \mathrm{~kg} / \mathrm{thm}$ (thm=ton hot metal) which accounts for $76 \%$ of the total $\mathrm{CO}_{2}$ emissions in ironmaking process. $24 \%$ of reduced $\mathrm{CO}_{2}$ is by gas recycling and the other $52 \%$ is transported and stored underground by CCS.

The test results show that the TGR-BF technology is easy to operate on the test blast furnace, with good safety, high efficiency and strong stability. The Version 4 had the best effect of emission reduction and was selected as the first choice for the trial on the industrial-scale blast furnace during the next stage.

\subsection{New Smelting Reduction Process (HIsarna)}

HIsarna is actually a highly merging of Cyclone Converter Furnace (CCF) and HIsmelt Smelt Reduction Vessel (SRV). The process flow is shown in Figure 2. HIsarna incorporates three new ironmaking technologies: (1) preheating and partial pyrolysis of coal in the reactor; (2) melting and prereduction of ore in the cyclone converter section; (3) final reduction and iron production in smelt reduction section [10].

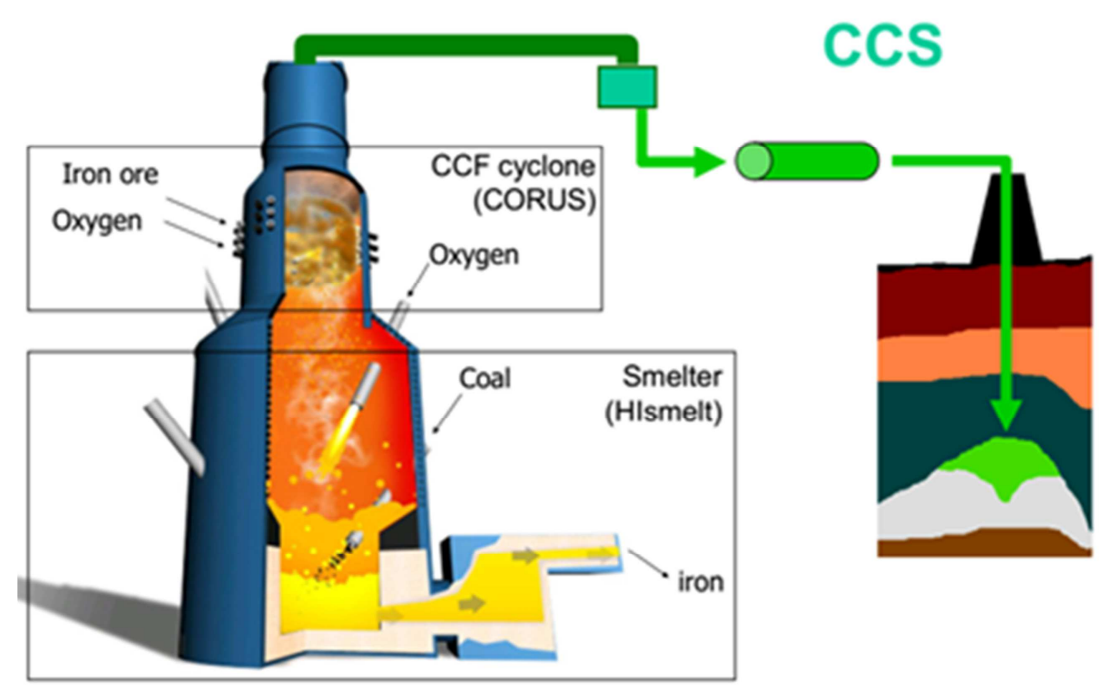

Figure 2. Process flow of HIsarna.

Iron ore and oxygen are injected into the CCF, where hot SRV offgas is totally burned and the resulting high temperature is used to melt and partially reduce the ore. The degree of pre-reduction can reach $10-20 \%$. Then the partly molten and reduced ore with the temperature of $1450^{\circ} \mathrm{C}$ runs downwards into the SRV. The chemical equation of the reduction reaction is as follows:

$$
\mathrm{Fe}_{\mathrm{x}} \mathrm{O}_{\mathrm{y}}(\mathrm{s})+\mathrm{CO} / \mathrm{H}_{2}(\mathrm{~g})=\mathrm{Fe}_{\mathrm{x}} \mathrm{O}_{\mathrm{y}-1}(\mathrm{l})+\mathrm{CO}_{2} / \mathrm{H}_{2} \mathrm{O}(\mathrm{g})
$$

Flux decomposition and calcination reaction is shown in Equation (2) and Equation (3).

$$
\begin{gathered}
\mathrm{CaCO}_{3}(\mathrm{~g})=\mathrm{CaO}(\mathrm{l})+\mathrm{CO}_{2}(\mathrm{~g}) \\
\mathrm{CaMg}\left(\mathrm{CO}_{3}\right)_{2}(\mathrm{~s})=\mathrm{CaO}(\mathrm{l})+\mathrm{Mg}(\mathrm{l})+2 \mathrm{CO}_{2}(\mathrm{~g})
\end{gathered}
$$

The coal is decomposed and preheated in the coal decomposition furnace, then is injected into the bath at high speed (using nitrogen as carrier gas) to dissolve carbon into the hot metal. The temperature of metal bath reach $1400-1450^{\circ} \mathrm{C}$ with dissolved carbon $4.0 \%$. The heat required for partially decomposition is from the combustion of volatiles, which reduces the need for heat in the bath.

Molten ore collides to the wall of the CCF and falls into bath, and then reacts with the carbon in the semi-coke, which takes place in the lower part of SRV and is strongly endothermic. The reaction is shown in Equation (4) and Equation (5).

$$
\begin{gathered}
\mathrm{Fe}_{2} \mathrm{O}_{3}(\mathrm{l})+[\mathrm{C}]_{\mathrm{Fe}} / \mathrm{C}(\mathrm{s})=\mathrm{FeO}(\mathrm{l})+\mathrm{CO}(\mathrm{g}) \\
\mathrm{FeO}(\mathrm{l})+[\mathrm{C}]_{\mathrm{Fe}} / \mathrm{C}(\mathrm{s})=\mathrm{Fe}(\mathrm{l})+\mathrm{CO}(\mathrm{g})
\end{gathered}
$$

Partly combusted gas leaving the SRV then provides the necessary hot fuel gas for the CCF. The hot fuel gas with temperature of $1450 \sim 1500^{\circ} \mathrm{C}$, containing $\mathrm{CO}_{2}$ generated 
during smelting, carrier gas and volatilized product of coal, moves upward and generates a large amount of splash. The droplets of metal and slag, carrying the heat generated by combustion, move from the upper section to the lower section of SRV. The number of droplets passing through the combustion zone is so large that the temperature of each droplet rises $10^{\circ} \mathrm{C}$ each time when it passes through the combustion zone. This allows heat to move downwards without compromising the oxygen potential gradient in the system (relatively oxidizing at the top, strongly reducing at the bottom).

The advantages of HIsarna lie in the following points:

(1) Ability to use thermal coals instead of metallurgical coals.

(2) Ability to use low-quality iron ore feed materials.

(3) Easy ability to capture a high proportion of $\mathrm{CO}_{2}$ for possible geological storage.

(4) $20 \%$ primary energy saving and $\mathrm{CO}_{2}$ reduction (without geological storage) [11].

HIsarna does not require the energy-intensive and heavily-polluting processes of sintering and coking in the conventional blast furnace route. In addition, due to the simple and once-through gas flow in the process, the $\mathrm{CO}_{2}$ content of flue gas stream is high enough to allow direct compression (with flash release of non-condensable gas components) for geological storage without the necessity for $\mathrm{CO}_{2}$ scrubber. HIsarna has the best performance in terms of carbon collection efficiency among all the ULCOS technologies. By using biomass or natural gas instead of coal, combined with CCS, heat and energy recover device, HIsarna technology reduces almost $70 \% \mathrm{CO}_{2}$ emission. This offers significant advantages in terms of capital cost, energy efficiency and carbon mitigation. HIsarna can reject $90 \%$ of phosphorous to slag, it opens the possibility of using the iron ores which normally are considered as high-phosphorous iron ore, and it has the potential to use titano-magnetite which is not suitable for blast furnace for some technical reasons. It offers more widely adaptation of raw material and better benefit for steelmakers.

In September 2010, the HIsarna pilot plant was set up n Holland Ijmuiden by TATA Iron and Steel Group with annual production reaches $65 \mathrm{kt}$. The design output of hot metal is 8 $\mathrm{t} / \mathrm{h}$, ore and coal injection capacity are $8 \mathrm{t} / \mathrm{h}$ and $15 \mathrm{t} / \mathrm{h}$ respectively. It will take at least 10 to 20 years for the HIsarna process to be put into industrialized application.

\subsection{New Direct Reduction Process (ULCORED)}

ULCORED process uses natural gas to direct reduce the iron ore and produce direct-reduced iron (DRI) which is sent to electric arc furnace (EAF) as raw material [12]. Natural gas or biomass gas replaces coke as the reducing agent, and the top gas cycle and preheating process are introduced to reduce the consumption of reducing agent. The electricity required for melting makes it less efficient in terms of energy consumption, and it also has more demanding requirement for the quality of iron ore used in the process. Therefore, this process is more expensive than conventional blast furnace process at present. However, the potential advantages of ULCORED are the removal of dependence on coke oven and to reduce natural gas consumption by replacing traditional reforming technology with partial oxidation of the natural gas. Combined with CCS device, ULCORED can reduce $70 \% \mathrm{CO}_{2}$ emission compared with the average blast furnace in Europe.

The research team is in the process of developing the technology of replacing reforming by partial oxidation of the natural gas to reduce natural gas consumption needed to produce DRI. This will also substantially reduce capital expenditure. The new layout will adopt a single source of $\mathrm{CO}_{2}$ that will be sufficiently clean for geological storage.

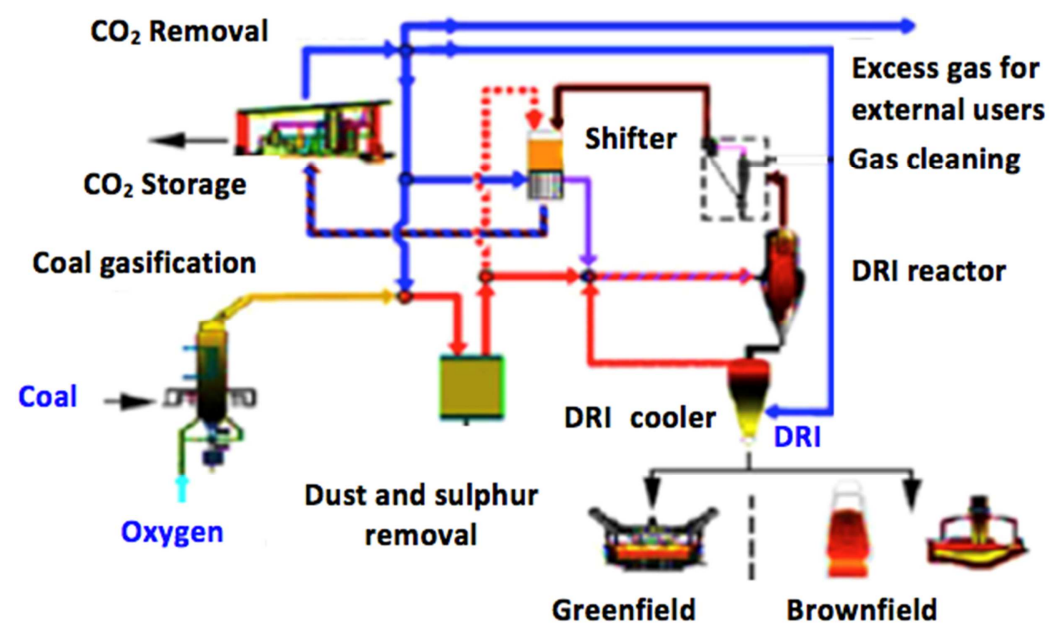

Figure 3. ULCORED direct reduction process.

\subsection{Alkaline Electrolytic Reduced Iron Process (ULCOWIN, ULCOLYSIS)}

This technology transforms iron ore into metal and oxygen by using only electricity. Since it does not require coke ovens, grate-rotary kiln, and blast furnace used in traditional ironmaking process, it can eliminate $\mathrm{CO}_{2}$ emissions and significantly reduce capital expenditure.

Although electrolysis of iron ore is the least developed process route currently being studied in ULCOS and no iron is 
presently produced by electrolysis, its attractiveness is that the technology of smelting metal such as aluminum, zinc and nickel by electrolysis is very mature. The most promising options for electrolysis are ULCOWIN (also called electrowinning) and ULCOLYSIS.

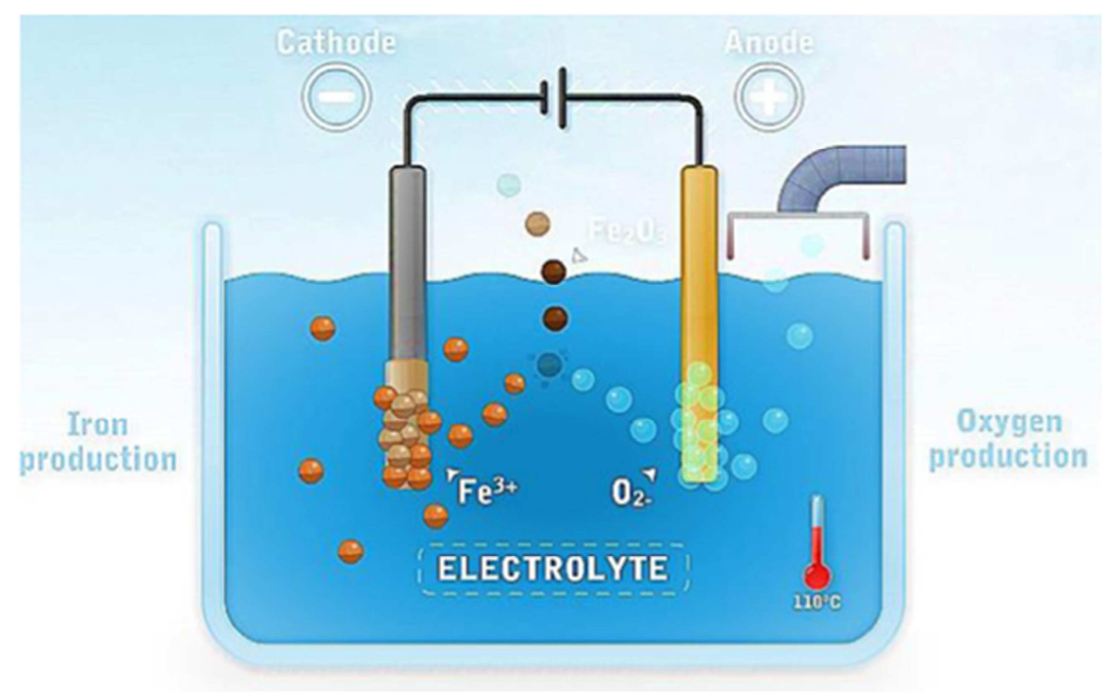

Figure 4. Principle of Iron Ore Electrolysis.

In the ULCOWIN process, iron ore particles are suspended in alkaline electrolyte $(\mathrm{NaOH})$ solution at $100 \sim 110^{\circ} \mathrm{C}$, and then electrolyzed by constant current. Oxygen ions with negative charge are attracted to the anode and continue to flow from the top of the solution. Iron ions with positive charge are attracted to the cathode, and the columnar iron crystal is deposited on the surface of the cathode [10].

The reactions occurring on the anode and the cathode are shown in Equation (6) and Equation (7), respectively, and the battery reaction is shown in Equation (8).

$$
\begin{gathered}
12 \mathrm{OH}^{-}=12 \mathrm{e}^{-}+3 \mathrm{O}_{2}+6 \mathrm{H}_{2} \mathrm{O} \\
2 \mathrm{Fe}_{2} \mathrm{O}_{3}+6 \mathrm{H}_{2} \mathrm{O}+12 \mathrm{e}^{-}=4 \mathrm{Fe}+12 \mathrm{OH}^{-} \\
2 \mathrm{Fe}_{2} \mathrm{O}_{3}=4 \mathrm{Fe}+3 \mathrm{O}_{2}
\end{gathered}
$$

The research conducted in the ULCOS I phase has shown the feasibility of small-scale applications. The purity of the iron obtained by the ULCOWIN process is up to $99.98 \%$, and the energy consumption is 2600 to $3000 \mathrm{~kW} \cdot \mathrm{h} / \mathrm{t}$. Although the energy consumption is reasonable, the production output of the pilot plant is only $5 \mathrm{~kg} / \mathrm{d}$. Therefore, the ULCOS research team developed the ULCOLYSIS (electrical direct reduction) process.

In the ULCOLYSIS process, iron ore dissolved in molten oxide solution at $1600^{\circ} \mathrm{C}$. This special electrolyte medium is chosen in order to operate at a temperature higher than the melting point of iron metal. The anode made of an inert material is impregnated in the liquid iron pool. The electrical current is flown between this anode and a liquid iron pool connected to the circuit as the cathode. Gaseous $\mathrm{O}_{2}$ evolves from the anode and liquid iron is produced at the cathode. The ULCOLYSIS process is still in the laboratory research stage and is expected to have breakthrough progress after 2030 .

\subsection{Support Technology for ULCOS [9]}

\subsubsection{Hydrogen-Based Steelmaking Technology}

Hydrogen-based steelmaking, iron ore is reduced to carbon-free DRI by using hydrogen as reducing agent, and DRI is processed in an electric furnace to produce steel, as the byproduct is just water, it can significantly reduce $\mathrm{CO}_{2}$ emissions by $80 \%$. Hydrogen is generated from steam reforming of natural gas or from electrolysis of water. The hydrogen used in the ULCOS program is from electrolysis of water. The electricity used to electrolyze the water comes from hydroelectric power stations and nuclear power plants. The $\mathrm{CO}_{2}$ emitted from hydrogen-based steelmaking is almost zero, even $\mathrm{CO}_{2}$ emitted because of electricity consumption is taken into account, the total $\mathrm{CO}_{2}$ emission is only $300 \mathrm{~kg} /$ ton steel, $\mathrm{CO}_{2}$ emission is reduced by $84 \%$ compared to current $\mathrm{CO}_{2}$ emission ( $1850 \mathrm{~kg} \mathrm{CO}_{2} /$ ton steel) in the blast furnace route.

Hydrogen-based steelmaking technology would be a promising sustainable route for steel production, however, it largely depends on the hydrogen economy, in other word, it would realize industrialized application in large-scale when $\mathrm{H}_{2}$ is available in large quantities and cost-competitive.

\subsubsection{Biomass-Based Ironmaking Technology}

Biomass mainly contains carbon $(\mathrm{C})$, hydrogen $(\mathrm{H})$, oxygen $(\mathrm{O})$, nitrogen $(\mathrm{N})$, and sulfur $(\mathrm{S})$ and $50 \mathrm{wt} \%(\mathrm{wt}=\mathrm{weight}$ percentage; dry matter, $\mathrm{dm}$ ) of carbon. The carbon content and the sulfur content in the wood biomass is low compared to fossil fuels such as coal, coke or oil used in ironmaking and steelmaking, which is advantageous for blast furnace ironmaking. The factors that are hindering the application of biomass-based steelmaking technology are: (1) environment disruption result from cultivation of biomass, for example deforestation, air and water pollution and biodiversity reduction; (2) undesirable social and economic impacts 
caused by using biomass such as food price soaring and migration of the people who originally live on the land used for cultivating the biomass.

Planting eucalyptus trees which can be converted to biomass for the biomass-based steelmaking in tropical countries is a very prospective solution. Brazil, where plantation and conversion technologies of eucalyptus are mature, built a small size blast furnace that uses $100 \%$ charcoal as reducing agent. At present, the cost of $\mathrm{CO}_{2}$ reduction by using biomass is very high, but it is still a flexible alternative to mitigate $\mathrm{CO}_{2}$ emission in the steel industry.

\subsubsection{Carbon Capture and Storage Technology}

Carbon capture and storage (CCS), $\mathrm{CO}_{2}$ produced by the combustion of fossil fuel is captured, then transported through pipelines to underground or by ships to the seabed for storage. This technology is considered to be the most effective solution to reduce greenhouse gas emission and slow down global warming at large-scale in future. There are three main types of carbon dioxide capture methods: pre-combustion, oxy-fuel combustion and post-combustion capture. Post-combustion capture first recovers and then seal $\mathrm{CO}_{2}$ in the flue gas emitted during ironmaking and steelmaking, it is well-aligned with the existing integrated iron-and steel production plant. It only needs to add a flue gas treatment process before the flue gas is discharged into the atmosphere, it does not require a large-scale transformation and the technology is mature. The main post-combustion capture technology includes absorption, adsorption, membrane separation, cryogenic separation, etc. $[13,14]$.

Three technologies under ULCOS incorporates the CCS, each technology test different kinds of CCS methods with different parameter settings. TGR-BF tested absorption such as amine scrubbing, adsorption such as VPSA or PSA and cryogenics separation on the experimental blast furnace, and VPSA showed the best performance in technology and economy with high concentration of $\mathrm{CO}_{2}$; For HIsarna, only a cryogenic separation unit is enough to obtain high purity of $\mathrm{CO}_{2}$. If CCS is deployed in others stack of the steel mill, and then an amine scrubbing unit would be the best solution.

However, CCS technology currently has technical uncertainties in terms of storage capacity and large-scale application, and its cost is also very high. It is estimated that the cost for storing carbon dioxide is between $€ 30 / \mathrm{t}-\mathrm{CO}_{2}$ and $€ 60 / \mathrm{t}-\mathrm{CO}_{2}$, and there may be environmental negative effects. Solving these problems is still the focus of research in various countries [15].

\section{Economic and Environmental Performances of ULCOS}

Compared with the average blast furnaces in Europe, the technologies of ULCOS have many advantages in energy consumption, carbon emissions, investment and operating costs.

Table 1. Environmental and economic performance of ULCOS compared with current EU average level for pig-iron production.

\begin{tabular}{|c|c|c|c|c|}
\hline & EU average $B F$ & TGR-BF & HIsarna & ULCORED \\
\hline Production capacity (Mt hm/year) & $0.5-5.0$ & $0.5-5.0$ & $0.5-1.0$ & $0.5-1.0$ \\
\hline Environmental performance & & & & \\
\hline $\begin{array}{l}\text { Energy consumption } \\
\mathrm{CO} 2 \text { emission }(\mathrm{t} / \mathrm{t} \mathrm{hm})\end{array}$ & $100 \%$ & - & $80 \%$ & $85 \%-95 \%$ \\
\hline —with $C C S$ & 1650 & $790(\downarrow 52 \%)$ & $330(\downarrow 80 \%)$ & $760(\downarrow 54 \%)$ \\
\hline $\begin{array}{l}\text { —no CCS } \\
\text { Economic performance } \\
\text { CAPEX }\end{array}$ & 1650 & & $1320(\downarrow 20 \%)$ & $1590-1420(\downarrow 5 \%)$ \\
\hline -Greenfield & $100 \%$ & $105 \%$ & $75 \%$ & $200 \%$ (no CCS) \\
\hline -Brownfield & - & $25 \%$ & $65 \%$ & \\
\hline OPEX & $100 \%$ & $120 \%$ & $90 \%$ & $80 \%-90 \%($ no CCS $)$ \\
\hline
\end{tabular}

+1 The proportions should be interpreted as relative scores, the level of average blast furnace is set at $100 \%$, the other data are absolute figures.

$2 \mathrm{hm}=$ hot metal (or pig-iron).

In the aspect of environmental performance, the energy consumption of TGR-BF is not given, because although it uses top gas recycling to save the consumption of coke, $\mathrm{CO}_{2}$ separation still need extra electric power. Since HIsarna technology removes the processes of pelleting, sintering and coking, it is significantly more energy efficient, more environmentally friendly and more cost-effective than the blast furnace process. Besides, it does the best in aspects of energy consumption, $\mathrm{CO}_{2}$ emission and capital expenditure compared to the other innovative technologies of ULCOS. By combining with $\mathrm{CCS}$, it might reduce the $\mathrm{CO}_{2}$ emissions by $80 \%$. In the long run, ULCORED would be a feasible breakthrough technology that can reduce $\mathrm{CO}_{2}$ emissions by $80 \%$ to $95 \%$ when electricity is completely generated by the renewable energy. The current development is incomplete and many aspects are not evaluated.

In the aspects of economic performance, the capital investment and operation cost of TGR-BF is slightly increased, because in addition to the original blast furnace, the facilities to process the top gas and to recover the exhaust gas are added. However, the capital investment and operation cost of HIsarna is only $65 \%$ to $75 \%$ of blast furnace, as it removes the processes of pelleting, sintering and coking. The investment required for the ULCORED program is 1 time higher than that of the conventional blast furnace, and the operating cost (without the CCS unit) is about $80 \%$ to $90 \%$ of the blast furnace process. 


\section{Conclusions}

This paper highlights the current status and future trends of low-carbon steelmaking technology in Europe, as well as the innovative technologies for mitigating the $\mathrm{CO}_{2}$ emission from the steel industry of other countries in the world.

With the technical development and cost reduction of oxygen production and $\mathrm{CO}_{2}$ removal, TGR-BF that is improved based on the traditional blast furnace process is more feasible than other breakthrough technologies. ULCORED will have bright prospects in the countries where the price of natural gas is rather cheap.

HIsarna high proportion smelting reduction technology and alkaline electrolysis method do not need to use iron ore agglomerates and do not use metallurgical coke to make iron. It is an ideal iron-smelting process that can produce high-quality iron without pollution, although due to energy conversion. With regard to efficiency, the use of electric energy for iron making is currently not economically competitive. However, HIsarna technology is an important milestone in the development of non-coke ironmaking technologies in the future. It requires to increase the proportion of electric energy in the energy structure and significantly reduce the cost of electric energy. It is possible to achieve industrial-scale applications.

Faced with the threat of global warming, governments all over the world will adopt increasingly stringent environmental protection policies. The steel industry characterized with high energy-consumption and high pollution is bound to face an increasingly severe crisis of survival. In the long run, innovative steel production technologies will become effective solutions to alleviate greenhouse gas emissions from steel industry, despite it is now far from the level to be deployed in the steel industry. In addition to more extensive and in-depth research to overcome technical difficulties, it is also essential for the government to provide support in terms of fund and policy.

\section{References}

[1] Onarheim K, Mathisen A, Arasto A, "Barriers and opportunities for application of CCS in Nordic industry-A sectorial approach," International Journal of Greenhouse Gas Control, 2015, 6, pp. 93-105.

[2] Peng Jin, Zeyi Jiang, Cheng Bao, Shiyu Hao, Xinxin Zhang, "The energy consumption and carbon emission of the integrated steel mill with oxygen blast furnace," Journal of Cleaner Production, 2017, Vol. 117, pp. 58-65.
[3] Qi Zhang, Yu Li, Jin Xu, Guoyu Jia, "Carbon element flow analysis and $\mathrm{CO}_{2}$ emission reduction in iron and steel works," Journal of Cleaner Production, 2018, Vol. 172, pp. 709-723.

[4] Commission, E, "ULCOS-Perspectives," Available from: (http://www.ulcos.org/en/about_ulcos/perspectives.php).

[5] ULCOS, "Structure and financing," Available from: (http://www.ulcos.org/en/about_ulcos/structure_refinancing.php).

[6] Shigeaki Tonomura, Naoki Kikuchi, Natsuo Ishiwata, Shin Tomisaki, Yukio Tomita, "Concept and Current State of $\mathrm{CO}_{2}$ Ultimate Reduction in the Steelmaking Process (COURSE50) Aimed at Sustainability in the Japanese Steel Industry," Journal of Sustainable Metallurgy, 2016, Vol. 2, pp. 191 - 199.

[7] LUO Ye, WANG Chao, "Energy Saving and Emission Reduction Measures of Korean Iron and Steel Industry," Proceedings of the $11^{\text {th }}$ Annual Conference of China's Iron and Steel Industry- S15. Energy and Environment Protection, 2017, Beijing.

[8] M. Abdul Quader, Shamsuddin Ahmed, Raja Ariffin Raja Ghazilla, Shameem Ahmed, Mahidzal Dahari, "A comprehensive review on energy efficient $\mathrm{CO}_{2}$ breakthrough technologies for sustainable green iron and steel manufacturing," Renewable and Sustainable Energy Reviews, 2015, Vol. 50, pp. 594-614.

[9] Quader M A, Shamsuddin Ahmed, Dawal S Z, and Nukman Y, "Present needs, recent progress and future trends of energy-efficient Ultra-Low Carbon Dioxide $\left(\mathrm{CO}_{2}\right)$ Steelmaking (ULCOS) program," Renewable and Sustainable Energy Reviews, 2016, Vol. 55, pp. 537-549.

[10] WANG Dongyan, "Breaking-through iron-making technologies in ULCOS program," World Steel, 2011, Vol. 11, No. 2, pp. 7-12.

[11] K. Meijer, C. Guenther, R. J. Dry, "HIsarna Pilot Plant Program," Symposium on the 8th annual conference of China's iron and steel, 2011.

[12] WANG Dongyan, "Research and development of retrofitted ironmaking process in ULCOS project," World Iron \& Steel, 2011, Vol. 11, No. 1, pp. 29-37.

[13] S Tian, K Li, J Jiang, X Chen, F Yan, " $\mathrm{CO}_{2}$ abatement from the iron and steel industry using a combined $\mathrm{Ca}-\mathrm{Fe}$ chemical loop," Applied Energy, 2016, Vol. 170, pp. 345-352.

[14] S Tian, J Jiang, F Yan, K Li, X Chen, "Highly efficient $\mathrm{CO}_{2}$ capture with simultaneous iron and $\mathrm{CaO}$ recycling for the iron and steel industry," Green Chemistry, 2016, Vol. 18, pp. 4022-4031.

[15] Lin Zhu, Yangdong He, Luling Li, Pengbin Wu, "Tech-economic assessment of second-generation CCS: Chemical looping combustion," Energy, 2015, Vol. 144, pp. 915-927. 